\title{
STUDI PENGARUH VARIASI SUHU PERLAKUAN PANAS TERHADAP STRUKTURMIKRO DAN KOROSIFITAS PADA PELAPISAN SS 410 MENGGUNAKAN KOMPOSIT Ni-P-NANO PARTIKEL $\mathrm{Al}_{2} \mathrm{O}_{3}$
}

\author{
Yulinda Lestari $^{1}$, Efendi Mabruri ${ }^{1}$ dan Anne Zulfia Syahrial ${ }^{2}$ \\ ${ }^{1}$ Pusat Penelitian Metalurgi dan Material - LIPI \\ Gedung 470, Kawasan Puspiptek, Tangerang Selatan \\ ${ }^{2}$ Teknik Metalurgi dan Material, Fakultas Teknik - Universitas Indonesia \\ Kampus Baru UI, Depok \\ E-mail: yuli021@lipi.go.id
}

Diterima: 19 Desember 2016 Diperbaiki: 17 Maret $2017 \quad$ Disetujui: 5 April 2017

\begin{abstract}
ABSTRAK
STUDIPENGARUH VARIASISUHUPERLAKUANPANASTERHADAPSTRUKTURMIKRO DAN KOROSIFITAS PADA PELAPISAN SS 410 MENGGUNAKAN KOMPOSIT Ni-P-NANO PARTIKEL $\mathrm{Al}_{2} \mathrm{O}_{3}$. Pelapisan material Stainless Steel 410 dengan komposit Ni-P-nano powder $\mathrm{Al}_{2} \mathrm{O}_{3}$ menggunakan metode electroless kodeposisi sangat tergantung pada tingkat penggabungan lapisan komposit tersebut antara matriks Ni-P dan penguat nano partikel $\mathrm{Al}_{2} \mathrm{O}_{3} \mathrm{Hal}$ ini berpengaruh pada keunggulan sifat lapisan komposit seperti ketahanan korosi yang baik, laju deposisi yang cepat, keseragaman deposit yang dihasilkan dan ketahanan kimia yang baik. Pada penelitian ini, parameter yang divariasi adalah suhu perlakuan panas setelah proses electroless kodeposisi. Penelitian ini bertujuan untuk mengetahui fenomena strukturmikro, fasa dan kristalinitas, komposisi kimia dan distribusi unsur di permukaan coating, dan ketahanan korosi komposit coating Ni-P-nano partikel powder $\mathrm{Al}_{2} \mathrm{O}_{3}$. Substrat yang digunakan yaitu Stainless Steel 410 di-pretreatment untuk mengaktivasi permukaan, kemudian direndam dalam larutan yang terdiri dari nikel sulfat, natrium hypophosphite, ammonium sulfat, sodium asetat, lead asetat dan serbuk nano alumina. Substrat direndam selama 60 menit, dalam suhu proses $90 \pm 2^{\circ} \mathrm{C}$ dengan kecepatan putaran $150 \mathrm{rpm}$. Karakterisasi sampel dilakukan menggunakan alat SEM-EDS, XRD, dan CMS. Dari hasil percobaan menunjukkan terdapat perbedaan visual permukaan substrat antara logam dasar, setelah proses electroless coating dan setelah perlakuan panas. Berdasarkan variabel percobaan, untuk suhu perlakuan panas yang optimum adalah $400{ }^{\circ} \mathrm{C}$, dimana terbentuk strukturmikro dari nodular menjadi butiran yang lebih teratur dan merata serta memiliki ketahanan korosi yang paling baik.
\end{abstract}

Kata kunci: Pelapisan Material, Electroless Kodeposisi, Ni-P- $\mathrm{Al}_{2} \mathrm{O}_{3}$, Perlakuan panas, Struktur Mikro, Kristalinitas, Ketahanan korosi

\begin{abstract}
THE STUDY OF INFLUENCE HEAT TREATMENT TEMPERATURE ON THE MICROSTRUCTURE AND CORROSIVITY OF COATING SS 410 USING COMPOSITE Ni-P-PARTICLE NANO $\mathrm{Al}_{2} \mathbf{O}_{3}$. The Ni-P-particle nano powder $\mathrm{Al}_{2} \mathrm{O}_{3}$ composite coating have been prepared by electroless codeposition method. It has advantage that the process does not require an electrode, fast deposition rate, good corrosion and wear resistance. In this study, the variable parameters is the heat treatment temperatures after electroless codeposition process. The aim of this research is to determine microstructure phenomenon, phase and crystalinity, chemical composition and distribution on coating surface, and corrosivity $\mathrm{Ni}-\mathrm{P}$-nano powder $\mathrm{Al}_{2} \mathrm{O}_{3}$ composite coating. The substrate is used stainless steel 410 . Substrates have been pre treated in order to activate the surface. Then, substrate immersed in solution that consisting of nickel sulfate, sodium hypophosphite, ammonium sulfate, sodium acetate, lead acetate dan nano alumina powder. The substrate
\end{abstract}


is immersed about 60 minutes at a $90 \pm 2^{\circ} \mathrm{C}$ temperature with speed of $150 \mathrm{rpm}$. Sample characterization has done by SEM-EDS, XRD, and CMS. Results indicate there is a visual difference on coating surface before and after heat treatment process. Based on variable experinment, the optimum heat treatment temperature is $400{ }^{\circ} \mathrm{C}$ which have given the best microstructure and most excellent corrosion resistance.

Keywords : Material plating, Electroless co-deposition, Ni-P- $\mathrm{Al}_{2} \mathrm{O}_{3}$, Heat Treatment, Microstructure, Crystalinity, Corrosion Resistance

\section{PENDAHULUAN}

SS 410 merupakan material yang paling banyak digunakan di industri turbin blade ini hampir $90 \%$ pemakaiannya. Turbin blade ini merupakan bagian yang paling rentan terkena korosi dan erosi yaitu yang terkena beban dan pergerakan paling banyak. Oleh karena itu, untuk meningkatkan sifat-sifat material dan ketahanan korosinya dilakukan pelapisan. Pelapisan SS 410 dengan $\mathrm{Ni}-\mathrm{P}-\mathrm{Al}_{2} \mathrm{O}_{3}$ ini menggunakan metode electroless kodeposisi yaitu deposisi logam yang menggunakan proses reduksi autokatalitik dan tidak menggunakan elektroda, dan reaksi autokatalitik pada permukaan logam telah dimulai setelah nukleasi.

Aspek dasar yang dibutuhkan dalam sebuah electroless bath yaitu konsentrasi ion logam utama, reducing agents, complexing agents, bath stabilizers, kontrol pH dan suhu. Dalam proses deposisi electroless, ion logam direduksi ke logam dengan bantuan bahan kimia reducing agents, prinsipnya seperti donor elektron. Ion logam merupakan penerima elektron, yang berekasi dengan donor elektron. Proses ini autokatalitik, dimana mempercepat reaksi kimia electroless mengikuti oksidasi reducing agent yang digunakan. Berikut diagram dasar peralatan yang biasa digunakan dalam percobaan electroless seperti yang ditunjukkan pada Gambar 1:

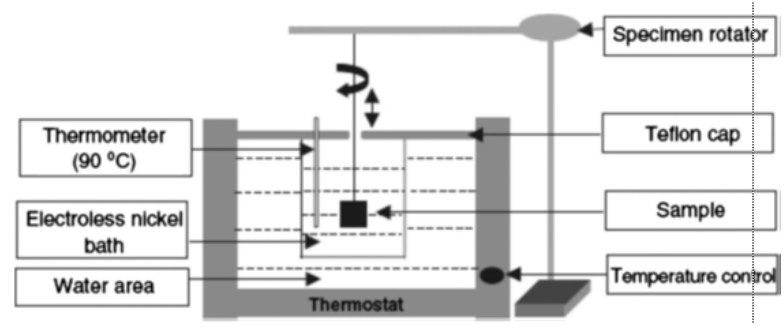

Gambar 1. Diagram dasar peralatan dalam percobaan Electroless [1].

Banyak reducing agent yang telah dikomersialisasi seperti sodium hypophosphite, amino boranes, sodium borohydride, dan hydrazine. Dalam penelitian ini dipilih reducing agent sodium hypophosphite karena deposisi electroless dengan hypophosphite bath memiliki banyak kelebihan dibandingkan dengan boron atau hydrazine bath. Hypophosphite bath biayanya lebih murah dan memberikan ketahanan korosi yang lebih baik [2]. Percobaan penggabungan partikel di fasa kedua dalam electroless matriks nikel ini dimulai dari tahun 1960an [3]. Keuntungan utama pembuatan coating komposit dengan electroless kodeposisi adalah bentuknya mengikuti geometri yang sesuai dan mengeliminasi penggunaan finishing mekanik [4].

Electroless coating komposit dibentuk dengan tumbukan dan pengendapan partikel pada permukaan benda kerja, dan selanjutnya partikel ini diselubungi dengan matriks material seperti yang dilapisinya. Tidak ada ikatan molekul antara partikel dan matriks logam [5]. Beberapa faktor yang mempengaruhi penggabungan patikel keras/halus ke dalam matriks electroless Ni-P yaitu bentuk dan ukuran partikel, densitas relatif partikel, muatan partikel, ketidakreaktifan partikel, konsentrasi partikel dalam bath, metode dan derajat agitasi, kesesuaian partikel dengan matriks dan orientasi bagian yang dilapis [6]. Reddy et al. [7] merekomendasikan bahwa untuk mencapai integritas yang lebih baik antara partikel dan matriks electroless Ni-P, ukuran partikel harus menjadi kecil sehingga dapat diikat oleh matriks.

Untuk mendapatkan kombinasi optimum untuk hasil coating yang maksimal maka parameter coating perlu divariasikan dengan rentang yang spesifik. Ada 3 faktor berpengaruh seperti konsentrasi dari senyawa donor nikel (larutan nikel sulfat), konsentrasi reducing agent (larutan sodium hypophosphite) dan konsentrasi partikel pengisi (serbuk $\mathrm{Al}_{2} \mathrm{O}_{3}$ ) untuk mengontrol sifatsifat coating komposit yang dihasilkan [8]. Dari penelitian sebelumnya telah didapatkan bahwa komposisi nano partikel $\mathrm{Al}_{2} \mathrm{O}_{3}$ yang optimum adalah $10 \mathrm{gr} / \mathrm{l}$ [9]. Sehingga tujuan dari penelitian ini adalah mempelajari pengaruh variasi suhu perlakuan panas terhadap strukturmikro, fasa dan korosifitas coating $\mathrm{Ni}-\mathrm{P}-\mathrm{Al}_{2} \mathrm{O}_{3}$ yang dihasilkan. Karena secara umum, perlakuan panas setelah proses electroless coating dapat memunculkan sifat unggul coating komposit seperti kekuatan dan ketahanan terhadap korosi karena perubahan strukturmikro akibat panas tinggi yang diberikan. Dari literatur disebutkan bahwa daerah suhu perlakuan panas yang optimal adalah sekitar $400^{\circ} \mathrm{C}$ selama 1 jam, dimana terjadi kristalisasi $\mathrm{Ni}$ dan presipitasi fasa $\mathrm{Ni}_{3} \mathrm{P}$ [10].

\section{METODE PERCOBAAN}

Pada percobaan ini digunakan substrat Stainless steel 410, karena aplikasi coating komposit ini drencanakan untuk turbin blade di Pembangkit listrik tenaga Panas Bumi (PLTP). Pelapisan pada stainless steel sulit karena masalah aktivasi pada permukaannya. Proses pre-treatment memegang peranan penting untuk mendapatkan pelindung coating yang baik pada 
stainless steel. Keberhasilan deposisi tergantung dari penghilangan lapisan tipis, pasivasi permukaan lapisan oksida pada stainless steel. Hal ini diatasi dengan pembersihan awal.Substrat yang digunakan berbentuk rod.

Pertama-tama permukaan substrat dibersihkan secara mekanik dari produk korosi dan yang berlemak dengan larutan detergen kemudian dibilas dengan air distilasi, dan dietsa dengan $\mathrm{HNO}_{3}$ (Merck, USA) $10 \mathrm{~mL}$, $\mathrm{HCl}$ (Merck, USA) $20 \mathrm{mLdan} \mathrm{H}_{2} \mathrm{O} 30$ mLpada suhu kamar selama 2 menit setelah itu dibilas kembali dalam air distilasi. Substrat diaktivasi dalam $\mathrm{PdCl}_{2}$ (Merck, USA) 0,6 gr/l + HCl 5 mLpada suhu kamar selama 10 menit, setelah itu dibilas dalam air distilasi dengan ultrasonic cleaning selama 1 menit. Terakhir, substrat dikenakan dengan $\mathrm{NaH}_{2} \mathrm{PO}_{2}$ (Merck, USA) selama 10 menit kemudian dibilas dengan air distilasi dan siap untuk proses electroless coating [1]. Komposisi kimia logam dasar berdasarkan uji menggunakan alat Spark-OES yaitu ditunjukkan pada Tabel 1.

\begin{tabular}{cc}
$\begin{array}{l}\text { Tabel 1. Komposisi kimia } \\
\text { standar stainless steel } 410 .\end{array}$ \\
\hline Elemen & \%Berat \\
\hline $\mathrm{C}$ & 0,033 \\
$\mathrm{Mn}$ & 0,34 \\
$\mathrm{Si}$ & 0,68 \\
$\mathrm{Cr}$ & 12,8 \\
$\mathrm{Mo}$ & 0,002 \\
$\mathrm{Ni}$ & 0,155 \\
$\mathrm{~S}$ & 0,0012 \\
$\mathrm{P}$ & 0,0162 \\
$\mathrm{Fe}$ & 85,85 \\
\hline
\end{tabular}

Serbuk nano partikel $\mathrm{Al}_{2} \mathrm{O}_{3}$ (Merck, USA) yang digunakan berukuran kira-kira $30 \mathrm{~nm}$ hingga $60 \mathrm{~nm}$ sebanyak $10 \mathrm{~g} / \mathrm{L}$. Serbuk nano alumina ini dicampur air distilasi kemudian diultrasonik selama 30 menit [11]. Komposisi bahan untuk membuat larutan dalam bath dipilih berdasarkan komposisi optimum dari beberapa referensi [9,12-14]. Komposisi larutan Ni-P diperlihatkan pada Tabel 2.

Tabel 2. Komposisi bath Ni-P- $\mathrm{Al}_{2} \mathrm{O}_{3}$

\begin{tabular}{lc}
\hline Nikel sulfat (Merck, USA) & $27 \mathrm{gr} / \mathrm{l}$ \\
Sodium hypophosphite (Merck, USA) & $24 \mathrm{gr} / 1$ \\
Ammonium Sulfat (Merck, USA) & $15 \mathrm{gr} / 1$ \\
Sodium Acetate (Merck, USA) & $10 \mathrm{gr} / 1$ \\
Lead acetate (Merck, USA) & $2 \mathrm{mg} / 1$ \\
Nano Powder $\mathrm{Al}_{2} \mathrm{O}_{3}$ (Merck, USA) & $10 \mathrm{~g} / 1$ \\
& \\
$\mathrm{pH}$ & $5-6$ \\
Temperatur & $90^{\circ} \mathrm{C}$ \\
Rpm & 150 \\
Perlakuan panas & $300-500^{\circ} \mathrm{C}, 1 \mathrm{jam}$ \\
\hline
\end{tabular}

Bahan-bahan kimia yang digunakan adalah grade analitik dan penambahan air distilasi dalam bath hingga $250 \mathrm{~mL}$. Sel elektrokimia disambungkan dengan substrat Stainless steel 410 yang terendam larutan electroless selama 60 menit. pH diatur tetap pada range dengan penambahan larutan asam klorida atau ammonium hidroksida. Variasi suhu diatur dan dikontrol dengan stirrer $150 \mathrm{rpm}$. Berat deposit dievaluasi perubahannya pada berat substrat sebelum dan sesudah proses electroless [15]. Substrat hasil electroless coating kemudian di perlakuan panas dengan variasi suhu $300{ }^{\circ} \mathrm{C}$ hingga $500{ }^{\circ} \mathrm{C}$ selama 1 jam karena berdasarkan literatur merupakan waktu optimum dimana terjadi kristalisasi $\mathrm{Ni}$ dan presipitasi fasa $\mathrm{Ni}_{3} \mathrm{P}$ [10]. Substrat hasil proses kemudian dikarakterisasi dengan peralatan sebagai berikut:

\section{Uji Strukturmikro/Nano Partikel}

Bertujuan untuk mengetahui distribusi partikel dalam coating dan tingkat keberhasilan penggabungan partikel dalam matriks Ni-P/Ni-B. Alat yang digunakan adalah Scanning Electron Microscope (SEM) merk Jeol 6390a, Jepang dengan perbesaran 500x.

\section{Uji Fasa}

Bertujuan untuk mengetahui fasa coating komposit yang dihasilkan apakah kristalin atau amorphous dengan cakupan sudut difraksi $2 \theta$ antara $0-100^{\circ}$. Diukur dengan menggunakan alat X-Ray Diffraction merk Shimadzu XRD 7000 Maxima X, Jepang dengan material anode $\mathrm{Cu}$ dan kecepatan scan 2 derajat/menit.

\section{Uji Korosi}

Bertujuan untuk mengetahui ketahanan coating komposit yang dihasilkan terhadap lingkungan korosif. Performa sampel coating dalam lingkungan korosi dievaluasi dalam larutan $\mathrm{NaCl} 3,5 \%$ dengan metode Electrochemical Impedance Spectroscopy (EIS), Electrochemical Noise (EN), dan Potentiodynamic polarization menggunakan alat Corrosion Measurement System (CMS) merk Gamry G750, USA dengan scan rate $1 \mathrm{mV} / \mathrm{s}$.

\section{HASIL DAN PEMBAHASAN}

\section{Analisis Pengamatan Visual}

Setelah proses electroless coating dilakukan proses penimbangan untuk mengetahui perubahan berat substrat kemudian diamati visualnya untuk mengetahui terdapat perbedaan sebelum dan sesudah proses. Berikut gambar visual permukaan substrat sebelum, setelah proses elestroless coating dan sesudah proses perlakuan panas pada Gambar 2.

Dari Gambar 2 terlihat jelas ada perbedaan warna permukaan substrat SS 410 sebelum proses electroless coating, sesudah proses electroless coating dan sesudah perlakuan panas. Sebelum proses coating, substrat berwarna terang mengkilat memantulkan cahaya. Karena stainless steel terdiri dari paduan logam yang 

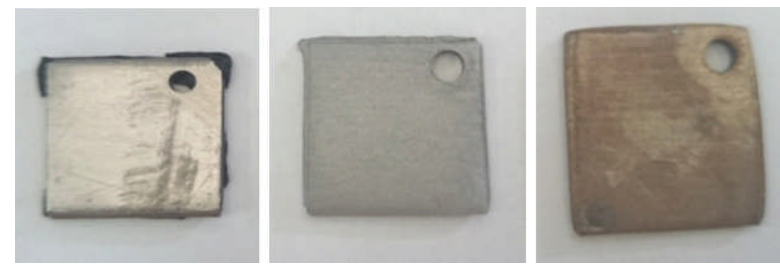

Gambar 2. Pengamatan Visual: (a). sebelum proses electroless coating (b). setelah proses electroless coating dan (c). setelah proses perlakuan panas.

komposisinya sebagian besar logam Fe. Setelah proses electroless coating, substrat berubah warna menjadi silver dove, karena sudah tertutupi dengan coating $\mathrm{Ni}-\mathrm{P}-\mathrm{Al}_{2} \mathrm{O}_{3}$. Substrat yang telah dilapisi kemudian diberi perlakuan panas, menghasilkan perubahan warna substrat menjadi keemasan karena proses pembakaran suhu tinggi.

\section{Analisis Strukturmikro}

Strukturmikro morfologi material coating masingmasing variabel suhu perlakuan panas ditunjukkan pada Gambar 3. Gambar 3(a) merupakan morfologi permukaan material logam dasar SS 410 setelah dilakukan
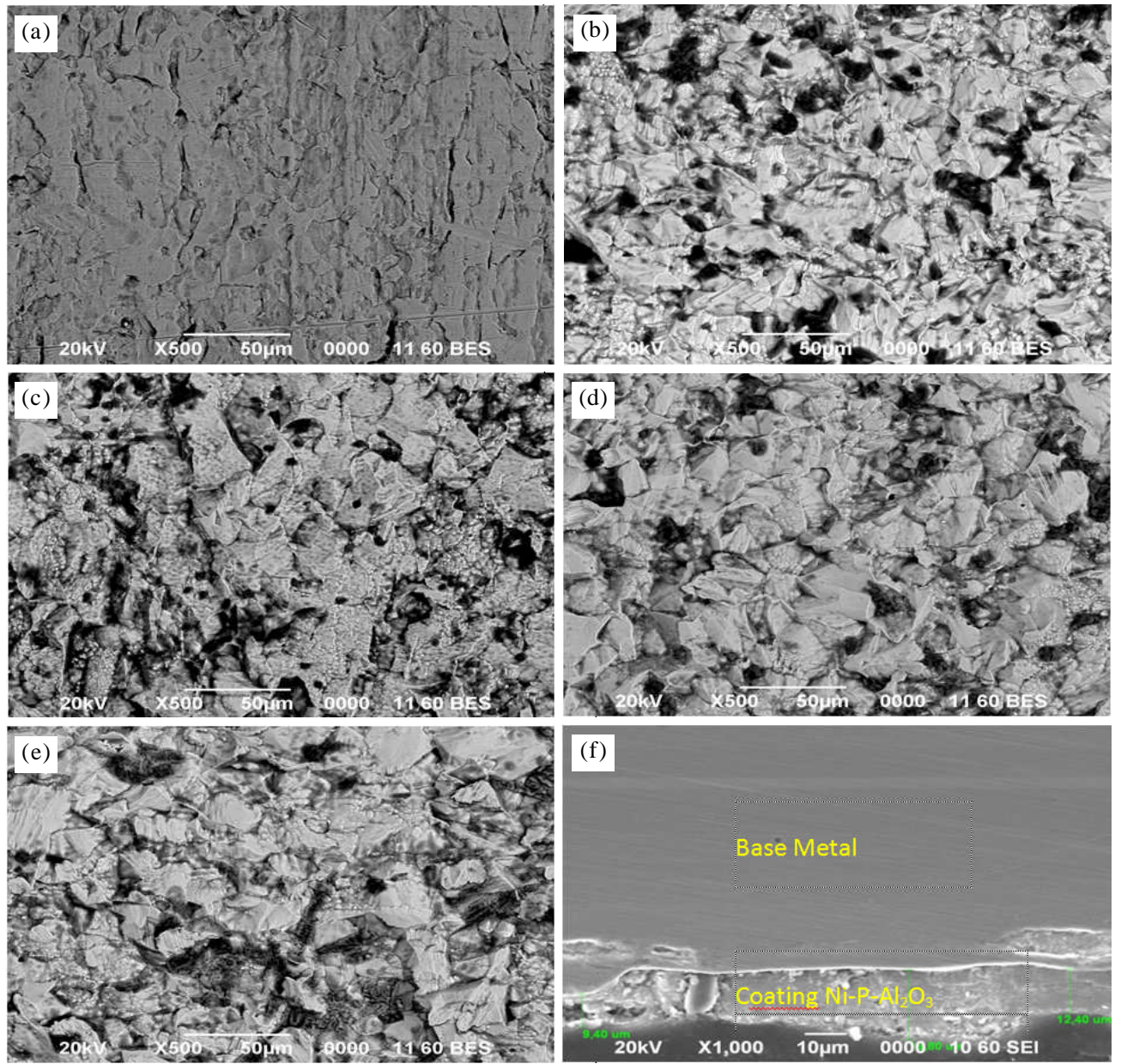

Gambar 3. Strukturmikro permukaan substrat dengan variasi komposisi suhu perlakuan panas (a). Logam dasar (b). Coating non perlakuan panas (c). Perlakuan panas $300{ }^{\circ} \mathrm{C}$ (d). Perlakuan panas $400{ }^{\circ} \mathrm{C}$ (e). Perlakuan panas $500{ }^{\circ} \mathrm{C}$ dan (f). Penampang melintang $\mathrm{T}=400{ }^{\circ} \mathrm{C}$. 
sehingga dipilih untuk menganalisis pengaruh variasi suhu perlakuan panas. Dari Gambar 3(b) terlihat permukaan substrat sebagian besar tertutupi oleh coating. Tetapi tanpa perlakuan perlakuan panas penggabungan komposit terlihat belum merata, nodular yang terbentuk pun masih tumpang tindih dengan partikel $\mathrm{Al}_{2} \mathrm{O}_{3}$. Maka perlu dilakukan perlakuan perlakuan panas setelah proses electroless coating untuk lebih menguatkan coating agar tidak rapuh dan mudah mengelupas ketika di lingkungan yang ekstrim.

Suhu optimum untuk perlakuan panas coating Ni-P adalah $300-500{ }^{\circ} \mathrm{C}$. Pada suhu perlakuan panas $300{ }^{\circ} \mathrm{C}$, dari Gambar 3(c) terlihat bahwa persebaran pembentukan komposit coating lebih merata. Penggabungan antara nodular dan partikel terlihat merata di permukaan substrat. Perlakuan panas memberikan efek yang signifikan terhadap strukturmikro dan sifat-sifat material.

Jika coating tanpa perlakuan perlakuan panas permukaannya terlihat lebih smooth maka dari Gambar 3(d), untuk perlakuan perlakuan panas pada suhu $400{ }^{\circ} \mathrm{C}$ terbentuk struktur butir-butir kasar [17]. Suhu perlakuan panas yang tinggi mengubah struktur nodular dan partikel kecil menjadi butiran-butiran. Ukurannya lebih besar dibandingkan nodular karena pengaruh suhu yang tinggi membuat nodular bersatu membentuk butiran.

Ketika suhu perlakuan panas dinaikkan menjadi $500^{\circ} \mathrm{C}$, terlihat dari Gambar 3(e) terbentuk butiran-butiran tetapi struktur permukaannya menjadi tidak merata. Karena pada suhu $550{ }^{\circ} \mathrm{C}$ coating Ni-P membentuk kristalin maka pada suhu $500{ }^{\circ} \mathrm{C}$ sebagian sudah berubah menjadi kristalin.

Untuk melihat lapisan coating yang terbentuk maka dilakukan SEM melintang, dari Gambar 3(f) dapat terlihat terbentuk lapisan coating $\mathrm{Ni}-\mathrm{P}-\mathrm{Al}_{2} \mathrm{O}_{3}$ dengan rata-rata ketebalan $17 \mu \mathrm{m}$.

\section{Analisis Fasa dan Kristalinitas}

Perbandingan hasil $X R D$ masing-masing variasi suhu perlakuan panas ditunjukkan pada Gambar 4. Berdasarkan hasil $X R D$ pada Gambar 4 menunjukkan semua coating yang dihasilkan memiliki struktur amorf. Peak tertinggi di $45^{\circ}$ berlokasi di semua deposit coating nikel dimana berhubungan dengan profil amorf deposit electroless nikel. Jumlah partikel $\mathrm{Al}_{2} \mathrm{O}_{3}$ dalam substrat terlalu rendah (kurang dari 5\%w dilihat dari Tabel 3 komposisi $\mathrm{Al}$ dan $\mathrm{O}$ ), sehingga puncak diffraksi $\mathrm{Al}_{2} \mathrm{O}_{3}$ tidak bisa terlihat di pattern XRD. Peak Fe yang terdeteksi dalam coating dimana ketebalan coating lebih rendah daripada kedalaman difusi X-ray ketika mengobservasi puncak substrat [18]. Untuk Stainless steel 410 yang merupakan tipe martensit dengan penambahan unsur logam lain seperti kromium dan sedikit nikel, tidak terlihat peaknya yang terbaca hanya peak Fe. Karena peak yang terbaca menandakan fasa bukan unsur tunggal. Ion $\mathrm{Cr}$ berada pada fasa alpha dalam peak Fe.

Tetapi dari data mikrostruktur telah dibahas adanya perubahan setelah proses electroless coating, juga data komposisi kimia yang didapatkan dari pengukuran SEM-EDAX pada Tabel 3 yang menunjukkan bahwa komposisi unsur utama pembentuk stainless steel semakin bertambah seiring dengan kenaikan suhu perlakuan panas sedangkan unsur pembentuk coating seperti $\mathrm{Ni}, \mathrm{P}, \mathrm{Al}$ dan $\mathrm{O}$ semakin berkurang. Hal ini disebabkan karena proses perlakuan panas mengubah strukturmikro dari nodular menjadi bentuk butiran. Sehingga coating yang tadinya memiliki fasa amorf berubah menjadi fasa kristalin substrat stainless steel 410.

Table 3. Perbandingan komposisi unsur di permukaan substrat dengan variasi suhu perlakuan panas.

\begin{tabular}{cccccc}
\hline \multirow{2}{*}{ Unsur } & \multicolumn{5}{c}{$\%$ Mass } \\
\cline { 2 - 6 } & Logam & Non & HT & HT & HT \\
& Dasar & HT & $300^{\circ} \mathrm{C}$ & $400^{\circ} \mathrm{C}$ & $500^{\circ} \mathrm{C}$ \\
\hline $\mathrm{Fe}$ & 83,74 & 77,52 & 79,22 & 79,55 & 79,47 \\
$\mathrm{Cr}$ & 12,13 & 11,66 & 11,87 & 11,58 & 12,09 \\
$\mathrm{Ni}$ & 0,14 & 3,04 & 2,90 & 2,88 & 2,91 \\
$\mathrm{P}$ & - & 1,97 & 1,47 & 1,15 & 1,13 \\
$\mathrm{Al}$ & - & 0,27 & 0,21 & 0,16 & 0,02 \\
$\mathrm{O}$ & - & 4,43 & 3,35 & 3,40 & 3,31 \\
\hline
\end{tabular}

Gambar 5 merupakan grafik perbandingan suhu perlakuan panas terhadap perubahan kandungan $\mathrm{P}$ dalam

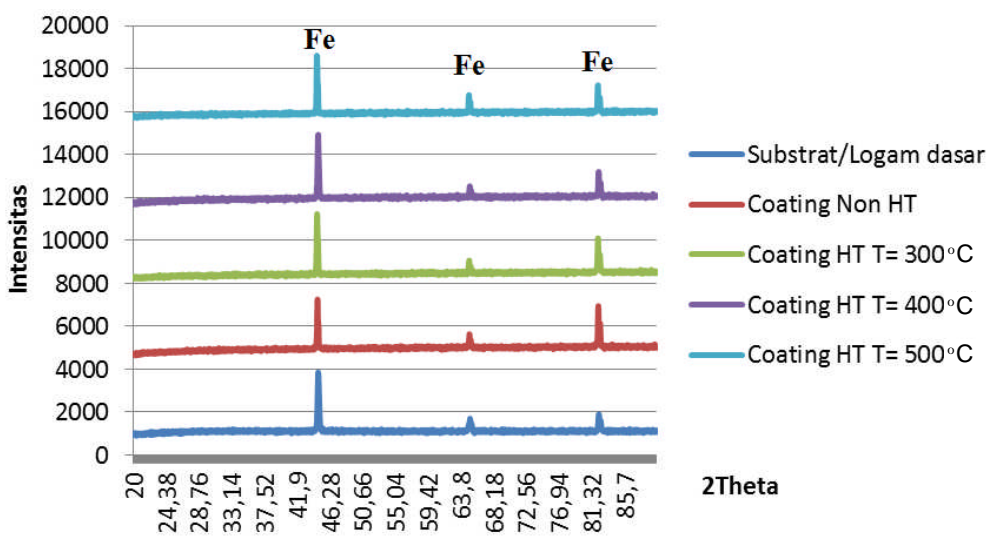

Gambar 4. Grafik perbandingan data $X R D$ variasi suhu perlakuan panas. 
Coating Dari Gambar 5 terlihat penurunan kandungan unsur $\mathrm{P}$ dalam coating. Pengurangan kompisisi unsur $\mathrm{P}$ pada coating sangat berpengaruh pada ketahanan korosinya. Secara umum, ketahanan korosi coating Ni$\mathrm{P}$ akan meningkat seiring dengan bertambahnya kandungan $\mathrm{P}$ [19].

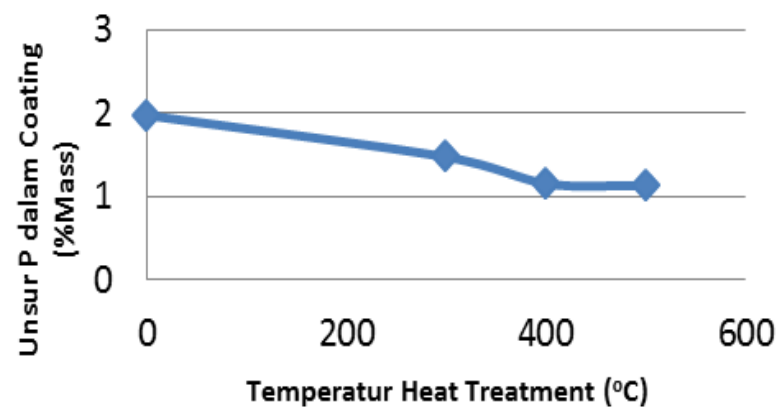

Gambar 5. Grafik perbandingan suhu perlakuan panas terhadap perubahan kandungan $\mathrm{P}$ dalam coating.

\section{Analisis Korosifitas}

Uji korosifitas menggunakan grafik tafel pada alat CMS untuk membandingkan laju korosi antar variabel percobaan. Dari uji tafel ini kemudian didapatkan nilai laju korosi yang disajikan pada Gambar 6 .

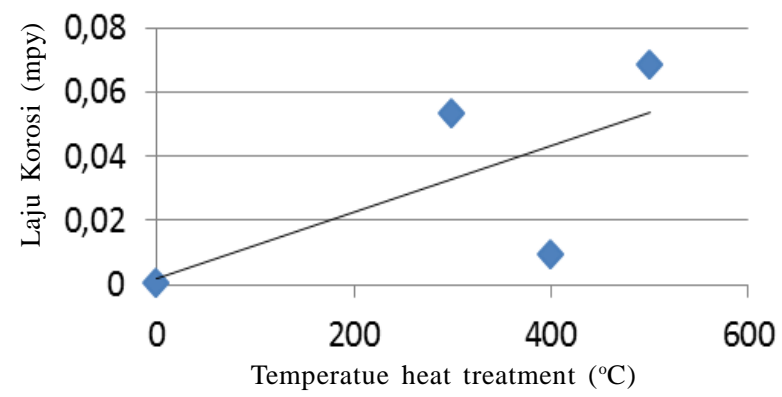

Gambar 6. Grafik linier laju korosi coating Ni-P- $\mathrm{Al}_{2} \mathrm{O}_{3}$ dengan variasi suhu perlakuan panas.

Gambar 6 menunjukkan nilai laju korosi, dimana semakin kecil laju korosi maka semakin baik ketahanan korosinya. Dari grafik tersebut terlihat laju korosi paling kecil adalah pada sampel dengan suhu perlakuan panas $400{ }^{\circ} \mathrm{C}$. Hal ini terkait dengan perubahan bentuk strukturmikro yang awalnya nodular setelah diberi perlakuan panas berubah menjadi butiran, maka ketahanan korosinya menurun karena struktur butir cenderung mengalami inisiasi korosi dan mikro crack di batas butir. Hal ini diperkuat dengan data komposisi unsur di permukaan substrat pada Tabel 3 dimana komposisi unsur pembentuk coating seperti Ni, P, Al dan $\mathrm{O}$ cenderung berkurang seiring dengan kenaikan suhu perlakuan panas.

Selain uji tafel, dilakukan juga uji cyclic untuk mengetahui ketahanan korosi material dalam kondisi cyclic dinamis. Dari uji cyclic ini didapatkan data potensial repasifasi dan potensial pitting seperti ditunjukkan pada Tabel 4. Data uji cyclic pada Tabel 4
Tabel 4. Tabel perbandingan cyclic dengan variasi suhu.

\begin{tabular}{ccc}
\hline Sampel & Potensial Repasivasi & Potensial Pitting \\
\hline Tanpa Coating & $-382,8 \mathrm{mV}$ & $-203,1 \mathrm{mV}$ \\
Tanpa Perlakuan panas & $64,69 \mathrm{mV}$ & $682,1 \mathrm{mV}$ \\
Perlakuan panas 300 C & $-362,4 \mathrm{mV}$ & $-110,2 \mathrm{mV}$ \\
Perlakuan panas 400 $\mathrm{C}$ & $-446,2 \mathrm{mV}$ & $319 \mathrm{mV}$ \\
Perlakuan panas 500 C & $-244,5 \mathrm{mV}$ & $-199,6 \mathrm{mV}$ \\
\hline
\end{tabular}

menunjukkan potensial repasifasi lebih kecil dibandingkan potensial pitting. Hal ini menandakan tidak terjadi korosi pitting selama uji cyclic berlangsung. Pitting merupakan jenis korosi terlokalisasi yang menimbulkan lubang pada material, yaitu pada daerah serangan korosi dimana luasnya relatif lebih kecil dibandingkan seluruh permukaan yang terekspos.

Sedangkan repasivasi merupakan proses ketika permukaan logam kembali menjadi pasif. Sehingga ketika repasivasi terjadi lebih dahulu maka di permukaan logam sudah terbentuk lapisan protektif untuk melindungi permukaan dari korosi pitting. Pada awal imersi, terjadi ketidakstabilan arus dan semakin stabil seiring bertambahnya waktu. Arus akan fluktuatif karena lapisan pasif masih dalam proses pembentukan. Hal ini juga berhubungan dengan teori Ion Competitive antara oksigen terlarut dan ion klorida untuk teradsorbsi ke permukaan logam. Fenomena seperti ini juga bisa diakibatkan karena overprotect yang terjadi saat awal pemberian arus proteksi. Semakin bertambahnya waktu, arus semakin stabil disebabkan terjadinya passivasi pada permukaan spesimen [20]. Semakin besar nilai potensial repasifasi maka semakin besar kebutuhan arus untuk membentuk lapisan pasif. Sehingga dari 5 variabel sampel yang diuji, sampel coating tanpa perlakuan panas membutuhkan waktu paling lama mencapai kondisi stabil dan membentuk lapisan pasif.

\section{KESIMPULAN}

Berdasarkan karakterisasi dan analisis hasil percobaan coating $\mathrm{Ni}-\mathrm{P}-\mathrm{Al}_{2} \mathrm{O}_{3}$ dengan metode electroless kodeposisi maka dapat disimpulkan terdapat perubahan strukturmikro di permukaan coating seiring dengan naiknya suhu perlakuan panas yang awalnya berbentuk nodular menjadi butiran-butiran yang berukuran lebih besar sehingga berpengaruh pada ketahanan korosinya. Analisis fasa menunjukkan semua variasi coating $\mathrm{Ni}-\mathrm{P}-\mathrm{Al}_{2} \mathrm{O}_{3}$ berada dalam fasa amorpous karena sedikitnya kadar $\mathrm{Ni}, \mathrm{P}$ dan $\mathrm{Al}_{2} \mathrm{O}_{3}$ di permukaan substrat sehingga fasa kristalin yang terbaca hanya $\mathrm{Fe}$. Komposisi kimia unsur $\mathrm{Ni}, \mathrm{P}, \mathrm{Al}$ dan $\mathrm{O}$ semakin berkurang seiring dengan kenaikan suhu perlakuan panas, tetapi persebaran unsur di permukaan coating tidak terlalu terlihat berbeda secara signifikan. Ketahanan korosi coating Ni-P paling baik adalah pada suhue perlakuan panas $400{ }^{\circ} \mathrm{C}$. Dari uji cyclic menunjukkan Coating 
$\mathrm{Ni}-\mathrm{P}-\mathrm{Al}_{2} \mathrm{O}_{3}$ ini tidak rentan terjadi korosi pitting dalam lingkungan $\mathrm{NaCl} 3,5 \%$.

\section{UCAPAN TERIMAKASIH}

Penulis mengucapkan terima kasih kepada Kegiatan Tematik P2MM-LIPI Tahun 2015 yang telah memberikan dana sehingga penelitian ini dapat berjalan lancar. Penulis juga mengucapkan terima kasih kepada Angga-Mahasiswa magang dari UNSRI-Palembang karena telah membantu kegiatan penelitian ini.

\section{DAFTAR ACUAN}

[1]. J. Sudagar, J. Lian, and W. Sha. "Electroless Nickel, Alloy, Composite and Nano Coatings-a Critical Review." Journal of alloys and compounds, vol. 571, pp. 183-204, 2013.

[2]. R. Sun, G. Yu, Z. Xie, B. Hu, X. He and X. Zhang. "Influence of Hypophospite on Efficiency and Coating Qualities of Electroless Ni-P Deposits on Magnesium Alloy AZ91D." International Journal Electrochemical Science, vol. 10, pp. 7893-7904, 2015.

[3]. W. Metzger and Th Florian. "The Deposition of Dispersion Hardened Coatings By Means of Electroless Nickel." Transactions of the Institute of Metal Finishing Journal, vol 54, no. 174, 1976.

[4]. S.R. Allahkaram, S. Salmi, and E. Tohidlou, "An Investigation on Effect of $\mathrm{TiO}_{2}$ Nano-particles Incorporated in Electroless NiPCoatings Properties." International Journal of Modern Physics: Conference Series, vol. 5, pp. 833-840, 2012.

[5]. Martin Buchtík, Petr Kosár, Jaromír Wasserbauer, and Martin Zmrzlý. "Electroless Deposition of Ni$\mathrm{P} / \mathrm{SiO}_{2}$ Composite Coating." Acta Universitatis Agriculturae et Silviculturae Mendelianae Brunensis, vol. 64, no. 5, pp. 1458 -1464, 2016.

[6]. P. Gadhari, and P. Sahoo. "Mechanism of ElectroCatalytic Oxidation of Shikimic Acid on $\mathrm{Cu}$ Electrode Based on in situ FT-IRs and Theoretical Calculations." Portugaliae Electrochimica Acta, vol. 32, no. 2, pp. 137-156, 2014.

[7]. V. V. N. Reddy, B. Ramamoorthy, and P. K. Nair. "A study on The Wear Resistance of Electroless Ni-P/ Diamond Composite Coatings.” Wear, vol. 239, 2000.

[8]. SK Das, P Sahoo. "Influence Of Process Parameters on Microhardness of Electroless Ni-B Coatings", Advances in Mechanical Engineering, 2012.

[9]. Y. Lestari, E. Mabruri, and A. Z. Syahrial, "Coating Composite Study of Ni-P-nano $\mathrm{Al}_{2} \mathrm{O}_{3}$ with Electroless co-deposition Method." Journal of Metallurgy \& Material, vol. 31, no. 1, pp. 51-57, 2016.
[10]. P. Gadhari, and P. Sahoo. "Mechanism of ElectroCatalytic Oxidation of Shikimic Acid on $\mathrm{Cu}$ Electrode Based on In Situ FTIRS and Theoretical Calculations." Portugaliae Electrochimica Acta, vol. 33, no. 3, pp: 165-181, 2015.

[11]. M. Wang, W. Yi Dan, J. Fen Li, J. Feng Ding, G. Qing Zhou, and Q. Sheng Wang. "Preparation and Characterization of $\mathrm{Al}_{2} \mathrm{O}_{3}$ Nanoparticles with Dodecyl Trimethyl Ammonium Bromide as Surfactant.” AMM Journal, vol. 9, 2013.

[12]. Abdel Gawad, S.A., Baraka, A.M., Morsi, M.S., and Ali Eltoum, M.S.'Development of Electroless Ni-

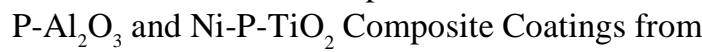
Alkaline Hypophosphite Gluconate Baths and Their Properties." International Journal of Electrochemical Science, vol. 8, pp. 1722-1734, 2013.

[13]. T. Radu, M. Vlad, F. Potecasu, and G.G. Istrate, "Preparation and Characterization of Electroless Ni-P- $\mathrm{Al}_{2} \mathrm{O}_{3}$ Nanocomposite Coatings.” Journal of Nanomaterials and Bostructures, vol. 10, pp. 1055-1065, 2015.

[14]. I. K. Hong, H. Kim, and B. S. Lee. "Optimization of Barrel Plating Process for Electroless Ni-P Plating." Journal of Industrial and Engineering Chemistry, vol. 20, pp. 3767-3774, 2014.

[15]. S. Kundu, S. K. Das, and P. Sahoo. "Properties of Electroless Nickel at Elevated Temperature a Review.” Procedia Engineering, vol. 97, pp. 1698$1706,2014$.

[16]. P. Gadhari, and P. Sahoo. "Effect of Process Parameters on Corrosion Resistance of Ni-P- $\mathrm{Al}_{2} \mathrm{O}_{3}$ Composite Coating Using Electrochemical Impendance Spectorscopy." Portugaliae Electrochimica Acta, vol. 33 (1), pp. 49-68, 2015.

[17]. P. Gadhari, and P. Sahoo, Procedia Materials Science, Effect of Process Parameters on Microhardness of $\mathrm{Ni}-\mathrm{P}-\mathrm{Al}_{2} \mathrm{O}_{3}$ Composite Coatings." Procedia Materials Science, vol. 6, pp. 623-632, 2014.

[18] M. Islam, M. R. Azhar, N. Fredj, and T. D. Burleigh. "Electrochemical Impendance Spectroscopy And Indentation Studies of Pure and Composite Electroless Ni-P Coatings." Surface and Coating Technology, vol. 236, pp. 262-268, 2013.

[19] S. Afroukhteh, C. Dehghanian and M. Emamy. "Preparation of Electroless Ni-P Composite Coatings Containing Nano-Scattered Alumina in Presence of Polymeric Surfactant." Progress in Natural Science: Materials International, vol. 22, no. 4, pp. 318-325, 2012.

[20] Febrianto. “Analisis Fluktuasi Arus Korosi Saat Hancurnya Lapisan Pasif dan Repasifasi oleh Ion Klorida.” Proceeding Seminar Nasional ke-15 Teknologi dan Keselamatan PLTN Serta Fasilitas Nuklir, 2009. 